\title{
Milk lactoferrin in heifers: Influence of health status and stage of lactation
}

\author{
L. Chaneton, ${ }^{* 1}$ M. Bontá, $†$ M. Pol, † L. Tirante,† and L. E. Bussmann* \\ *Instituto de Biología y Medicina Experimental, Vuelta de Obligado 2490, Buenos Aires 1428, Argentina \\ †Lactodiagnóstico Sur SRL, Olivos 1636, Buenos Aires, Argentina
}

\section{ABSTRACT}

The objective of the current study was to analyze the variations in lactoferrin (LF) concentrations in primiparous cows with intramammary infection and to study how the lactation stage affects these variations. In addition, we aimed to study the potential of the LF concentration in early lactation as a predictive factor for future infections. To accomplish this goal, a longitudinal analysis was performed for 96 primiparous cows. Milk samples were collected each month from individual quarters, and the LF concentration was determined for each sample. Criteria that included both somatic cell count (SCC) and a microbiological analysis were used to assess the health status of the quarters. Of the diseased quarters (SCC $>200,000$ or positive for pathogen isolation, or both), $62 \%$ corresponded to nonspecific mastitis (SCC >200,000 but microbiologically negative) and $25 \%$ corresponded to the category "presence of bacterial growth" (SCC $<200,000$ but microbiologically positive). Diseased quarters showed increased concentrations of LF compared with healthy quarters. However, this increase was greater during the first days of lactation compared with later periods. KaplanMeier analysis of time free of infection demonstrated that quarters with LF concentrations at early lactation $(3-10 \mathrm{~d}$ in milk) greater than $0.1 \mathrm{mg} / \mathrm{mL}$ are more likely to become infected during the following lactation compared with quarters with lower LF concentrations in early lactation. The results support that LF plays a relevant role in combating intramammary infection, particularly during the first days of lactation. In addition, we present evidence of the potential use of LF as a predictive marker of future infections in the individual quarters of dairy heifers.

Key words: mastitis, heifer, lactoferrin, early lactation

Received August 3, 2012.

Accepted May 3, 2013

${ }^{1}$ Corresponding author: lchaneton@bioimanay.com

\section{INTRODUCTION}

Bovine mastitis is one of the most deleterious diseases affecting dairy cows. The negative effect of mastitis is largely associated with economic losses that are primarily related to a decrease in milk production. Many strategies are currently used to control mastitis, including disinfection of udder teats pre- and postmilking, culling of chronically infected animals, total dry cow therapy, treatment of clinical cases, and proper maintenance of the milking machine (Neave et al., 1969; LeBlanc et al., 2006). The mammary gland, in turn, makes its own contribution to the fight against infection. It displays a set of mechanisms to prevent and combat IMI that have been classified as part of either an innate or adaptive immunity (Sordillo and Streicher, 2002; OviedoBoyso et al., 2007). Both mechanisms act in a tightly coordinated fashion and consist of cellular, soluble, and anatomical elements. As the first line of defense against invading pathogens, innate immunity plays a major role in mammary gland immunity (Wellnitz and Bruckmaier, 2012). Indeed, many lines of evidence suggest that impairment of the function of innate immunity is primarily responsible for the high prevalence of IMI during peripartum and early lactation (Mallard et al., 1998; Mehrzad et al., 2002).

Lactoferrin $(\mathbf{L F})$ is an $80-\mathrm{kDa}$ glycoprotein present in milk and in other body barrier fluids of vertebrates. Lactoferrin presents antibacterial activity that depends on its iron-chelating activity and on the direct interaction of its cationic amino-terminal region with the bacterial surface (Jenssen and Hancock, 2009). In the bovine mammary gland, LF plays a role in the defense against bacterial infection, particularly during the dry period when its concentration increases by 50 fold (Welty et al., 1976). In addition, LF concentration has been proven to increase during IMI, in both clinical and subclinical cases (Harmon et al., 1976; Hagiwara et al., 2003; Hyvönen et al., 2006; Chaneton et al., 2008). Many authors (Piccinini et al., 2007; Hiss et al., 2009) have reported that the LF concentration is also high during the first days of lactation, which is a finding that has been related to a possible function of LF in preventing the establishment of infection postpartum and in protecting the newborn calf from infections. 
Heifers represent both the productive and reproductive future of the dairy farm. It has been suggested that events in the mammary gland during the first lactation may affect the lactation performance throughout the entire productive life of the animal (Oliver et al., 2003). Because heifers have never experienced the stress of daily milking or clinical infection, they present unique immunological characteristics (Mehrzad et al., 2002). This fact is reflected in differences in prevalence and etiology of IMI between heifers and older cows (Tenhagen et al., 2006).

Although it is well demonstrated that bovine LF increases during IMI, it has not yet been established whether and how the lactational stage influences this increase. Moreover, little information exists concerning LF concentrations in primiparous cows.

The goal of this investigation was to establish a possible relationship between the period of lactation and the LF-mediated response to the infection of the mammary gland in primiparous cows. Additionally, we explored the potential use of LF as an indicator for the risk of future infections in the individual quarters of heifers.

\section{MATERIALS AND METHODS}

\section{Heifers and Samples}

Ninety-six primiparous Holstein cows from one herd under a pasture-based system were randomly selected for this study. None of the enrolled cows presented

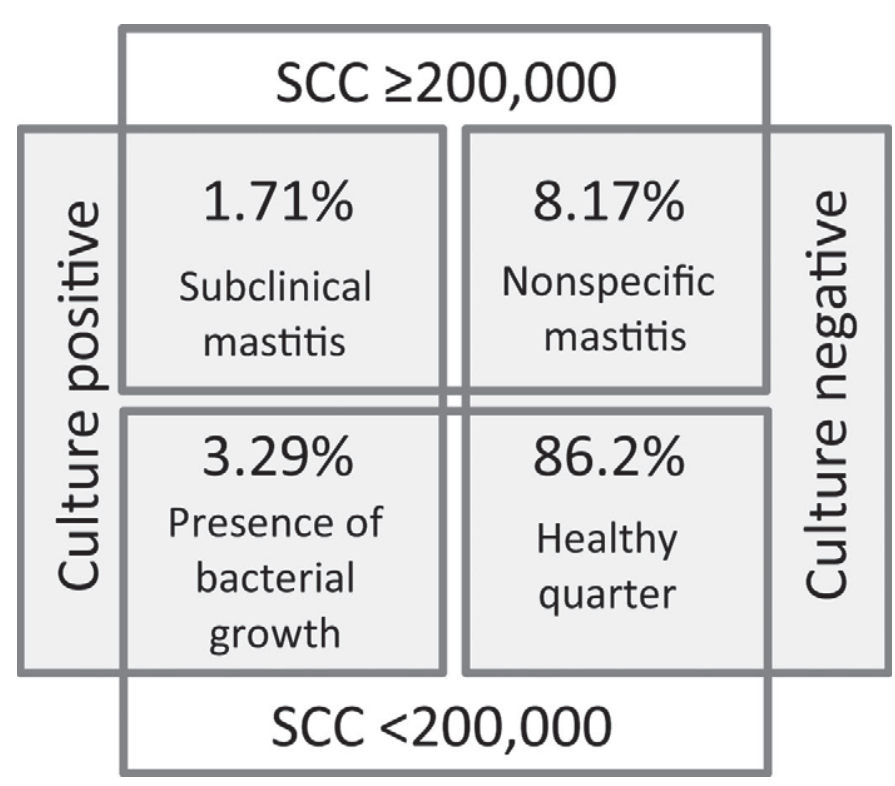

Figure 1. Summary of microbiological and SCC analyses of the 2,692 quarter samples analyzed in this study. external signs of infection (swelling, redness, pain in udder, or clots in milk) in any of the 4 quarters at the beginning of the sampling. Milk samples from individual quarters were collected as early as possible after the colostrum phase (3-10 d postcalving) and then once per month during the entire lactation or until the heifer was removed from the herd for other reasons. Foremilk was aseptically collected and frozen at $-18^{\circ} \mathrm{C}$ for 24 to $72 \mathrm{~h}$. Samples were cultured by plating $0.05 \mathrm{~mL}$ of milk on blood-esculin agar plates and incubated for 24 to 48 $\mathrm{h}$ at $37^{\circ} \mathrm{C}$. The isolation and identification of bacterial species were performed according to recommendations of the National Mastitis Council (Hogan et al., 1999). A microbiologically positive quarter was defined as isolation of 1 or 2 bacterial species from a quarter milk sample. Samples that presented 3 or more bacterial species in the plate were considered contaminated and were not used in this study. An aliquot of the same samples were also subjected to SCC analysis in a Somacount 300 cell counter (Bentley Instruments Inc., Chaska, MN) in the Littoral Association of Milk Control Entities (ALECoL; Esperanza, Santa Fe, Argentina).

Mammary gland quarters where classified into 4 categories according to the bacteriological analysis and SCC (Figure 1): (1) positive for pathogen isolation, with an SCC below 200,000 (presence of bacterial growth); (2) negative for pathogen isolation and an SCC equal to or greater than 200,000 (nonspecific mastitis); (3) positive for pathogen isolation and with an SCC above 200,000 (subclinical mastitis); or (4) negative for pathogen isolation and with an SCC below 200,000 (healthy quarters). Quarters with presence of bacterial growth, nonspecific mastitis, or subclinical mastitis where collectively classified as diseased quarters. The LF concentration was also evaluated in each sample by a competitive ELISA (see below).

\section{Quantification of LF}

The milk LF concentration was determined by a competitive ELISA: bovine LF antibodies generated as previously described (Chaneton et al., 2008) were used in a bovine LF (bLF)-biotin competitive ELISA. Bovine LF was purified as previously described (Chaneton et al., 2008) and biotinylated with biotinyl-e-aminocaproic acid-N-hydroxysuccinimide ester (NHS-LC-biotin; Pierce Chemical Co., Rockford, IL) according to the manufacturer's instructions. High-binding 96-well microtiter plates (Nunc A/S, Roskilde, Denmark) were coated with a $100 \mu \mathrm{L} /$ well bLF-specific antibody solution (3 $\mu \mathrm{g} / \mathrm{mL}$ in $200 \mathrm{mM} \mathrm{NaHCO} 3, \mathrm{pH}$ 8.3) and incubated overnight at $4^{\circ} \mathrm{C}$. Nonspecific binding was blocked by incubating plates with $10 \%$ normal goat serum [a kind gift from Alberto Koninckx, Centro Regional de Inves- 
tigaciones Científicas y Técnicas (CRICYT), Mendoza, Argentina] in TBS-Tween [Tris-buffered saline with $0.05 \%$ (vol/vol) Tween 20, $\mathrm{pH} 7.5$ ] for $2 \mathrm{~h}$ at room temperature $\left(20^{\circ} \mathrm{C}\right)$. Four microliters of whey from milk samples obtained by centrifugation, at $10,000 \times g$, of acidified milk was mixed with TBS-Tween containing $0.15 \mu \mathrm{g}$ of biotin-tagged LF to a final volume of 100 $\mu \mathrm{L}$. This mix was placed in duplicate into anti-bLF antibody-coated wells for $60 \mathrm{~min}$ at room temperature $\left(20^{\circ} \mathrm{C}\right)$. After incubation, wells were washed 4 times with TBS-Tween and incubated for an additional 60 min at room temperature $\left(20^{\circ} \mathrm{C}\right)$ with ExtraAvidinalkaline phosphatase (Sigma Chemical Co., St. Louis, MO) in TBS Tween. Wells were washed 4 times with high-salt TBS-Tween (TBS-Tween $+0.6 \mathrm{M} \mathrm{NaCl}, \mathrm{pH}$ 7.5 ), and the color reaction was allowed to develop by the addition of $0.5 \%$ (wt/vol) $p$-nitrophenyl phosphate in $100 \mathrm{~m} M$ Tris (pH 9.5) and $5 \mathrm{mM} \mathrm{MgCl}$. A calibration curve was prepared by serial dilutions of a bovine LF stock solution of a known concentration mixed with biotin-tagged LF in a manner similar to the milk whey samples. Absorbance at $405 \mathrm{~nm}$ was measured by a microplate reader, and the standard curve was generated by fitting its values to a 4-parameter logistic equation. The concentrations of LF in milk were determined by interpolating 405-nm absorbance values of samples into the calibration curve. Interassay and intraassay coefficients of variation were 16 and $7 \%$, respectively.

\section{Statistical Analysis}

All statistical analyses were performed with SPSS 15 for Windows (SPSS Inc., Chicago, IL). Analyses of the LF concentrations in healthy or diseased quarters and in different lactation periods were performed using a general linear model, with DIM, health status, pathogen, and milk production as fixed effects, and quarters nested within cows and cows as random effects. Interactions between DIM and health status and DIM and pathogen were also included in the model. The time effect within quarters was modeled by an autoregressive covariance matrix.

\section{RESULTS}

Of the total 2,692 samples analyzed, 391 (13.2\%) were diseased quarters (positive for microbial isolation or with SCC >200,000, or both). Of the total diseased quarters, $25 \%$ were positive for presence of bacterial growth, $62 \%$ corresponded to nonspecific mastitis, and $13 \%$ corresponded to subclinical mastitis (Figure 1). The most frequently isolated pathogen were CNS $(55.97 \%$ of the microbiologically positive quarters) followed by noncoliform gram-negative bacteria, coliforms, Staphy- lococcus aureus, Streptococcus uberis, Corynebacterium bovis, Streptococcus dysgalactiae, and Streptococcus spp. $(9.7,8.9,8.2,6.7,4.47,3$, and $3 \%$, respectively).

Diseased quarters were more frequent during the first month of lactation and gradually decreased thereafter (Figure 2A). A marked decrease in the percentage of quarters with presence of bacterial growths was observed after the first month of lactation. However, the rates of subclinical mastitis and nonspecific mastitis showed a more stable pattern over time (Figure 2B). Nonassociation between pathogen and stage of lactation was found $\left(\chi^{2}, P>0.05\right)$.

Diseased quarters showed higher concentrations of LF compared with healthy quarters $(P<0.001)$. However, no significant differences were observed between quarters positive for presence of bacterial growth, nonspecific mastitis, and subclinical mastitis $(0.12 \pm$ $0.03,0.11 \pm 0.01$, and $0.12 \pm 0.01 \mathrm{mg} / \mathrm{mL}$, respectively; Figure 3). Lactoferrin concentration was higher in quarters with coliforms, noncoliform gram-negative bacteria, Streptococcus spp. bacteria compared with healthy quarters (Figure 4). It is possible, however, that factors other than the infection status were affecting the LF concentration. Consequently, we decided to analyze the combined effects of both the health status and the lactation period in the LF concentration. When the health status and the days of lactation were considered, we observed that the increase in LF in diseased quarters was more pronounced during the first weeks of lactation than in mid and late lactation (interaction between days in milk and health status; $P<0.001$; Figure 5). Nonsignificant interaction was observed between pathogen and DIM.

To investigate whether the LF concentration is a predictive factor for future infections, we analyzed the time free of infection of the individual quarters sorted into 3 categories, according to the LF concentration in early lactation: less than $0.05 \mathrm{mg} / \mathrm{mL}$, between 0.05 and $0.1 \mathrm{mg} / \mathrm{mL}$, or higher than $0.1 \mathrm{mg} / \mathrm{mL}$. The results presented in Figure 6 show that the quarters with an LF concentration greater than $0.1 \mathrm{mg} / \mathrm{mL}$ in early lactation are more frequently infected during the following lactation compared with quarters with lower LF concentrations in early lactation.

\section{DISCUSSION}

Despite the efforts of dairy farmers and veterinarians, bovine mastitis remains one of the most deleterious diseases affecting dairy cows (Seegers et al., 2003). The understanding of the immune factors and mechanisms involved in the mammary gland defense against infection represents a fundamental task for improvements in the health, productivity, and welfare of dairy cattle. 


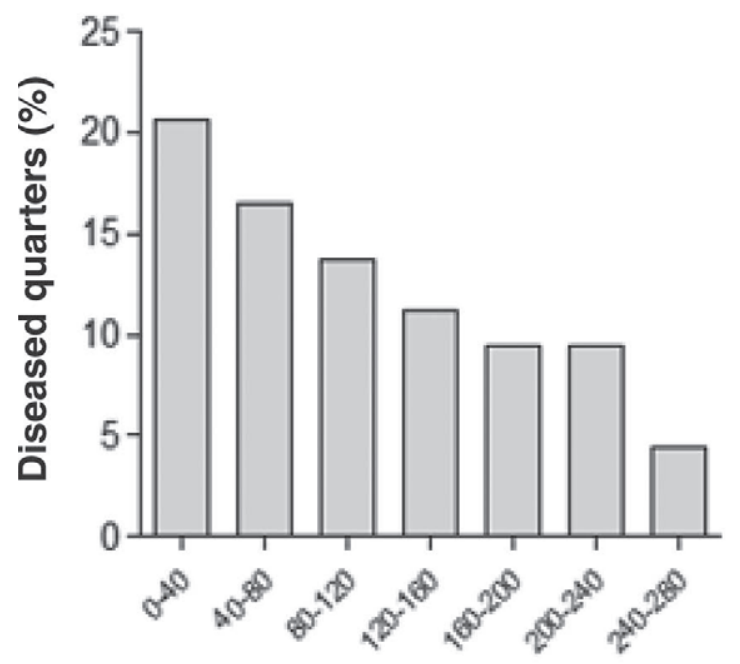

Days in milk

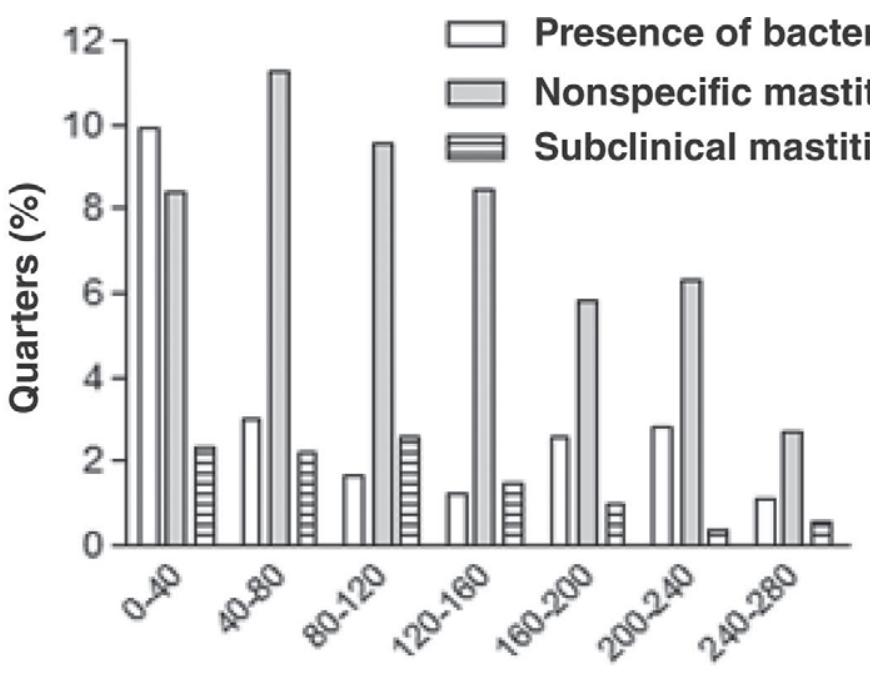

Days in milk

Figure 2. Association between lactation period and infection prevalence at quarter level. (A) Proportion of infected quarters at different lactation periods. (B) Proportion of quarters positive for presence of bacterial growth (white columns), nonspecific infection (gray columns), or subclinical mastitis (dashed columns) at different lactation periods.

In this study, we analyzed the concentration of LF in the mammary gland related to quarter health status and stage of lactation. Two combined variables were used to determine the quarter health status: the SCC value and the isolation of pathogenic bacteria. Similar criteria have been used by other authors (Pyörälä, 2003). Most of the samples with SCC levels higher than 200,000 were negative for bacterial isolation, which means that

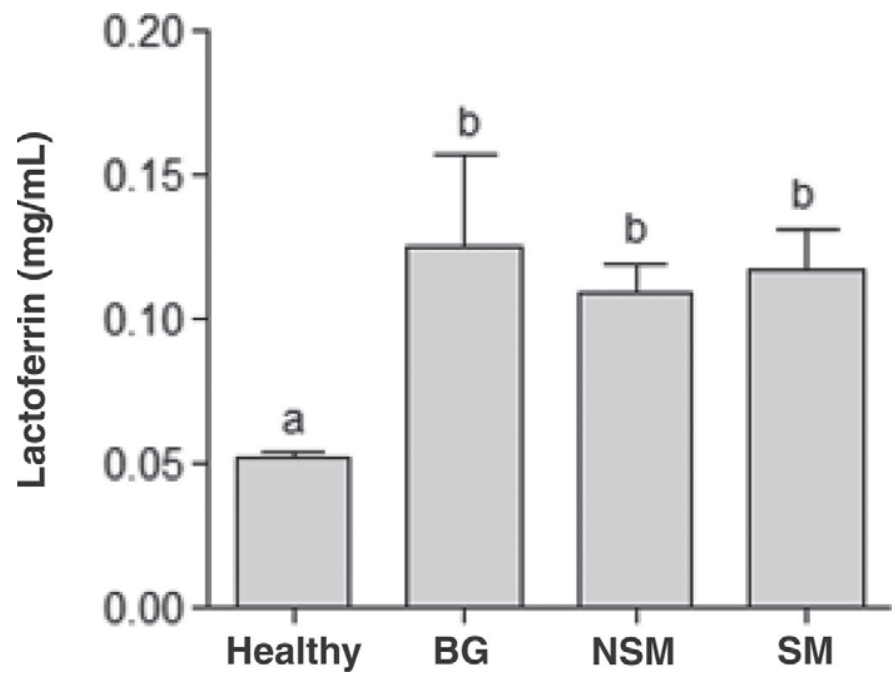

Figure 3. Lactoferrin in healthy and diseased quarters. Lactoferrin concentration (mean \pm SEM) in healthy quarters and quarters positive for presence of bacterial growth (BG), nonspecific mastitis (NSM), or subclinical mastitis (SM). Different letters ( $a$ and b) indicate significant differences $(P<0.001)$. an inflammation process can occur without detectable bacteria in milk. This result agrees with other studies showing clinically infected quarters that were not associated with the isolation of pathogenic bacteria but that were positive for mastitis-causing bacteria in realtime PCR analyses (Taponen et al., 2009). Conversely, a relatively high proportion of positive microbiological samples presented SCC values below 200,000. Two factors may explain this observation: first, some specific bacterial species could be associated with mild immune responses (Schwarz et al., 2010); second, it is possible

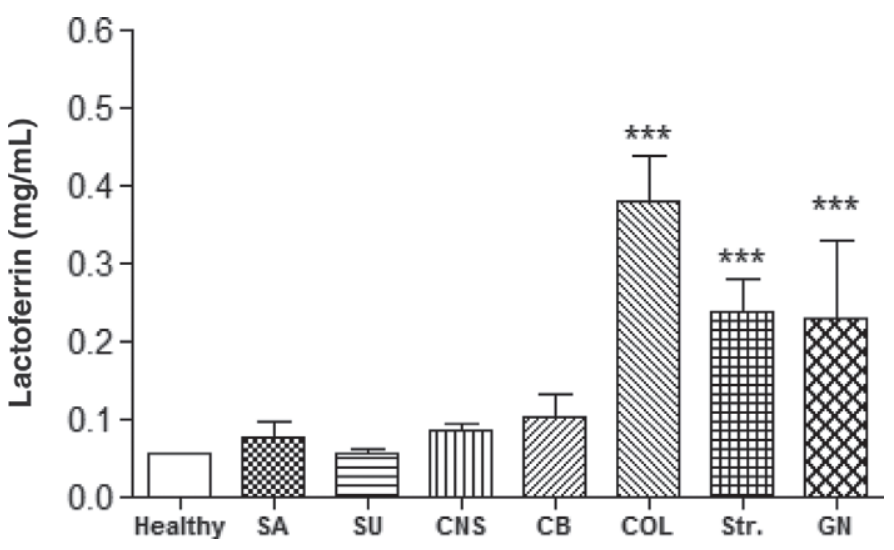

Figure 4. Lactoferrin associated with pathogen isolation. Lactoferrin concentration (mean $\pm \mathrm{SEM}$ ) in healthy quarters and quarters positive for Staphylococcus aureus (SA), Streptococcus uberis (SU), CNS, Corynebacterium bovis (CB), coliforms (COL), Streptococcus spp. (Str.), and noncoliform gram negative species (GN). ${ }^{* * *} P<$ 0.001, compared with healthy quarters. 


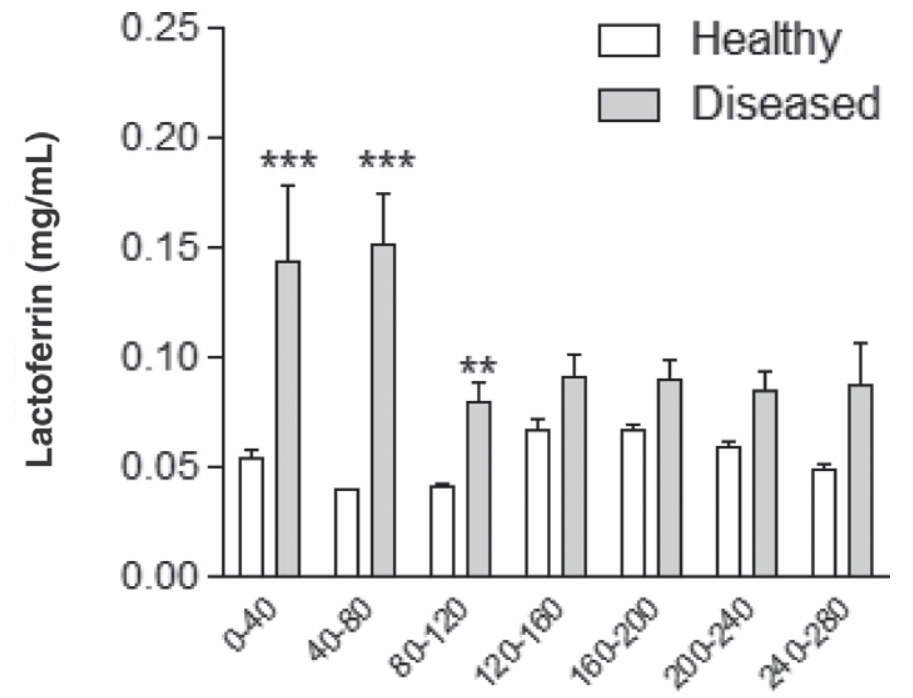

Days in milk

Figure 5. Lactoferrin concentration associated with time and health status. Lactoferrin concentration (mean \pm SEM) in healthy and diseased quarters at different periods of lactation. $* * * P<0.001$ and ${ }^{* *} P<0.01$ between healthy and diseased quarters from the same lactation period.

that the physiological status of the mammary gland could induce a diminished immune response upon bacterial invasion. A large body of evidence has documented immune suppression of the mammary gland during the first days of lactation (Compton et al., 2009). Accordingly, our results show that most quarters positive for presence of bacterial growth occur during the first 40 d of lactation, which suggests that, during this period, bacterial invasion occurs with little response from the mammary gland.

In this work, we present evidence showing that quarters with high levels of LF in early lactation are more likely to be infected throughout lactation than quarters with low levels of LF in early lactation. These results suggest that some specific quarters are highly susceptible to infection or are chronically infected, which could explain the association between a high LF concentration in early lactation and a high probability of detectable infection (pathogen isolation or SCC >200,000, or both) during lactation. Consistent with this hypothesis, De Vliegher et al. (2004) established that quarters with a high SCC in early lactation present higher SCC levels throughout the entire lactation. Those authors attributed this observation to an increased susceptibility or chronic infection in these quarters. Our observations suggest that the LF concentration could have a predictive value on the risk of future infections, which would have great practical applications for the control of mas-

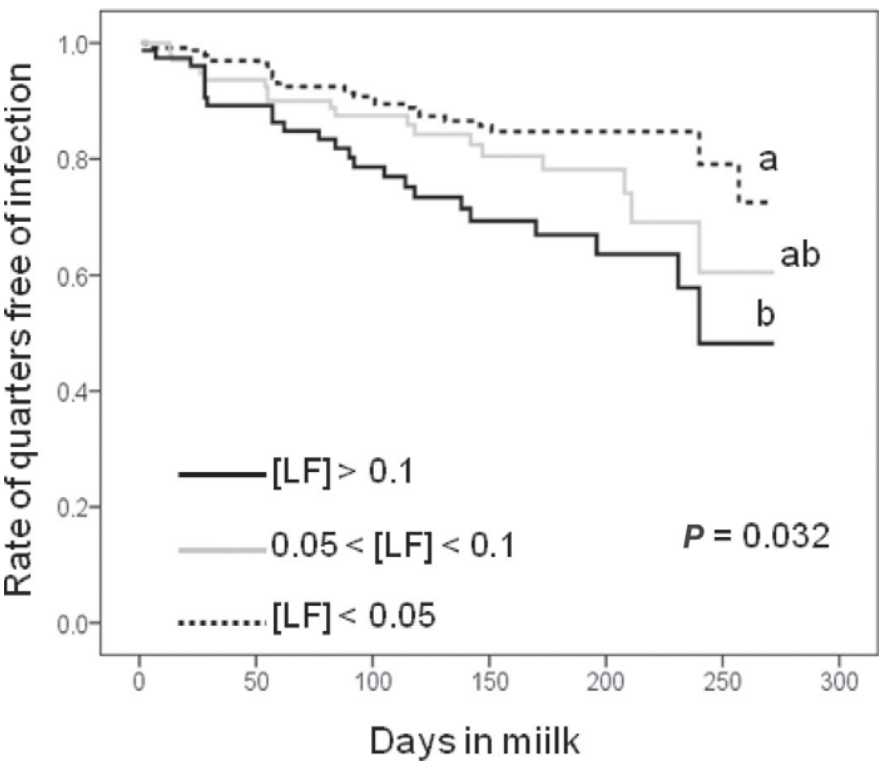

Figure 6. Association between lactoferrin (LF) concentration in early lactation and risk of infection. Kaplan-Meier plot of time free of disease in quarters that presented LF concentration below 0.05 $\mathrm{mg} / \mathrm{mL}$ (dashed line), between 0.05 and $0.1 \mathrm{mg} / \mathrm{mL}$ (gray line), and above $0.1 \mathrm{mg} / \mathrm{mL}$ (black line) in early lactation (3-10 d postpartum). Different letters $(\mathrm{a}$ and $\mathrm{b})$ indicate significant differences $(P<0.05)$.

titis on dairy farms. Nevertheless, further study should be conducted to strengthen this hypostasis.

Substantial literature has been published concerning the LF concentration in bovine mammary gland infections (Kutila et al., 2002; Chaneton et al., 2008; Cheng et al., 2008; Hyvönen et al., 2010). Nevertheless, this is the first study showing the combined effects of the lactation stage and naturally occurring infections on LF secretion.

\section{CONCLUSIONS}

The LF response to infection was more pronounced in the first days of lactation, suggesting that LF is a relevant factor in the innate immunity of the mammary gland during the first weeks of lactation. The role of LF in later stages of lactation was less clear. The fact that higher LF concentrations were associated with an increased probability of mastitis provides evidence that the physiological role of LF during lactation is to react against infections rather than to prevent them. Results to the contrary were found for other antimicrobial molecules, such as defensins, for which an augmented concentration in early lactation was associated with a diminished risk of infection.

\section{ACKNOWLEDGMENTS}

This work was supported by a grant from Agencia Nacional de Promoción Científica y Tecnológica 
(ANPCyT; Buenos Aires, Argentina; 21-34413). The authors are indebted to Julia Maito and Mercedes Gavidea for technical support. L. Chaneton is a fellow from CONICET and L. E. Bussmann is an established investigator from the same institution.

\section{REFERENCES}

Chaneton, L., L. Tirante, J. Maito, J. Chaves, and L. E. Bussmann 2008. Relationship between milk lactoferrin and etiological agent in the mastitic bovine mammary gland. J. Dairy Sci. 91:1865-1873.

Cheng, J. B., J. Q. Wang, D. P. Bu, G. L. Liu, C. G. Zhang, H. Y. Wei, L. Y. Zhou, and J. Z. Wang. 2008. Factors affecting the lactoferrin concentration in bovine milk. J. Dairy Sci. 91:970-976.

Compton, C. W. R., R. T. M. Cursons, C. M. E. Barnett, and S. McDougall. 2009. Expression of innate resistance factors in mammary secretion from periparturient dairy heifers and their association with subsequent infection status. Vet. Immunol. Immunopathol. 127:357-364

De Vliegher, S., H. W. Barkema, H. Stryhn, G. Opsomer, and A. de Kruif. 2004. Impact of early lactation somatic cell count in heifers on somatic cell counts over the first lactation. J. Dairy Sci. $87: 3672-3682$.

Hagiwara, S., K. Kawai, A. Anri, and H. Nagahata. 2003. Lactoferrin concentrations in milk from normal and subclinical mastitic cows. J. Vet. Med. Sci. 65:319-323.

Harmon, R. J., F. L. Schanbacher, L. C. Ferguson, and K. L. Smith. 1976. Changes in lactoferrin, immunoglobulin G, bovine serum albumin, and alpha-lactalbumin during acute experimental and natural coliform mastitis in cows. Infect. Immun. 13:533-542.

Hiss, S., C. Weinkauf, S. Hachenberg, and H. Sauerwein. 2009. Short communication: Relationship between metabolic status and the milk concentrations of haptoglobin and lactoferrin in dairy cows during early lactation. J. Dairy Sci. 92:4439-4443.

Hogan, J. S., R. S. Gonzalez, R. J. Harmon, S. C. Nickerson, S. P. Oliver, J. W. Pankey, and K. L. Smith. 1999. Laboratory Handbook on Bovine Mastitis. National Mastitis Council Inc., Madison, WI.

Hyvönen, P., T. Haarahiltunen, T. Lehtolainen, J. Heikkinen, R. Isomäki, and S. Pyörälä. 2010. Concentrations of bovine lactoferrin and citrate in milk during experimental endotoxin mastitis in early- versus late-lactating dairy cows. J. Dairy Res. 77:474-480.

Hyvönen, P., L. Suojala, T. Orro, J. Haaranen, O. Simola, C. Røntved, and S. Pyörälä. 2006. Transgenic cows that produce recombinant human lactoferrin in milk are not protected from experimental Escherichia coli intramammary infection. Infect. Immun. 74:6206-6212

Jenssen, H., and R. E. W. Hancock. 2009. Antimicrobial properties of lactoferrin. Biochimie 91:19-29.

Kutila, T., S. Pyörälä, L. Kaartinen, K. Vahtola, L. Myllykoski, and H. Saloniemi. 2002. Disposition kinetics of lactoferrin in milk after intramammary administration. J. Vet. Pharmacol. Ther. 25:129133
LeBlanc, S. J., K. D. Lissemore, D. F. Kelton, T. F. Duffield, and K. E. Leslie. 2006. Major advances in disease prevention in dairy cattle. J. Dairy Sci. 89:1267-1279.

Mallard, B. A., J. C. Dekkers, M. J. Ireland, K. E. Leslie, S. Sharif, C. L. Vankampen, L. Wagter, and B. N. Wilkie. 1998. Alteration in immune responsiveness during the peripartum period and its ramification on dairy cow and calf health. J. Dairy Sci. 81:585-595.

Mehrzad, J., L. Duchateau, S. Pyörälä, and C. Burvenich. 2002. Blood and milk neutrophil chemiluminescence and viability in primiparous and pluriparous dairy cows during late pregnancy, around parturition and early lactation. J. Dairy Sci. 85:3268-3276.

Neave, F. K., F. H. Dodd, R. G. Kingwill, and D. R. Westgarth. 1969 Control of mastitis in the dairy herd by hygiene and management. J. Dairy Sci. 52:696-707.

Oliver, S. P., M. J. Lewis, B. E. Gillespie, H. H. Dowlen, E. C. Jaenicke, and R. K. Roberts. 2003. Prepartum antibiotic treatment of heifers: Milk production, milk quality and economic benefit. J. Dairy Sci. 86:1187-1193.

Oviedo-Boyso, J., J. J. Valdez-Alarcón, M. Cajero-Juárez, A. OchoaZarzosa, J. E. López-Meza, A. Bravo-Patiño, and V. M. Baizabal-Aguirre. 2007. Innate immune response of bovine mammary gland to pathogenic bacteria responsible for mastitis. J. Infect. 54:399-409.

Piccinini, R., E. Binda, M. Belotti, V. Daprà, and A. Zecconi. 2007. Evaluation of milk components during whole lactation in healthy quarters. J. Dairy Res. 74:226-232.

Pyörälä, S. 2003. Indicators of inflammation in the diagnosis of mastitis. Vet. Res. 34:565-578.

Schwarz, D., U. S. Diesterbeck, K. Failing, S. König, K. Brügemann, M. Zschöck, W. Wolter, and C. P. Czerny. 2010. Somatic cell counts and bacteriological status in quarter foremilk samples of cows in Hesse, Germany-A longitudinal study. J. Dairy Sci. 93:5716-5728

Seegers, H., C. Fourichon, and F. Beaudeau. 2003. Production effects related to mastitis and mastitis economics in dairy cattle herds. Vet. Res. 34:475-491.

Sordillo, L. M., and K. L. Streicher. 2002. Mammary gland immunity and mastitis susceptibility. J. Mammary Gland Biol. Neoplasia $7: 135-146$

Taponen, S., L. Salmikivi, H. Simojoki, M. T. Koskinen, and S Pyörälä. 2009. Real-time polymerase chain reaction-based identification of bacteria in milk samples from bovine clinical mastitis with no growth in conventional culturing. J. Dairy Sci. 92:26102617

Tenhagen, B.-A. G. Köster, J. Wallmann, and W. Heuwieser. 2006. Prevalence of mastitis pathogens and their resistance against antimicrobial agents in dairy cows in Brandenburg, Germany. J. Dairy Sci. 89:2542-2551

Wellnitz, O., and R. M. Bruckmaier. 2012. The innate immune response of the bovine mammary gland to bacterial infection. Vet. J. $192: 148-152$

Welty, F. K., K. L. Smith, and F. L. Schanbacher. 1976. Lactoferrin concentration during involution of the bovine mammary gland. J. Dairy Sci. 59:224-231. 